\title{
Do head-restraints protect the neck from whiplash injuries?
}

\author{
F. MORRIS
}

Accident and Emergency Department, Oldchurch Hospital, Romford, Essex, England

\section{SUMMARY}

Over an 11-month period a study was made of all patients presenting to an accident and emergency department who had sustained whiplash as a result of rear-bumper impacts. The patients were analysed with respect to the presence of head-restraints in their vehicles. A significant increase in the incidence of whiplash was found in patients whose vehicles did not have head-restraints fitted. Legislation requiring all passenger cars to have head-restraints fitted as standard would have a major impact in reducing the number of whiplash injuries sustained in rear bumper impacts.

\section{INTRODUCTION}

Whiplash is a common and frequently underestimated injury, often giving rise to prolonged disability (Mersky, 1984). Rear bumper impacts are responsible for $85 \%$ of all whiplash injuries (Jackson, 1966; States et al., 1970; Hohl, 1974) and as many as 38\% of vehicle occupants exposed to this type of impact will develop symptoms (States et al., 1972).

It is estimated that there are 3800000 rear-end collisions in the USA annually (National Safety Council, 1971) (there are no comparable figures available from the UK Department of Transport), clearly constituting a major health problem. In an attempt to reduce the incidence of neck injuries sustained in this fashion, the US Department of Transportation required all passenger cars manufactured after 31 December 1968 to have head-restraints fitted as standard. However, the evidence that head-restraints play a major role in protecting vehicle occupants from whiplash injury was, and remains, unconvincing. Several studies, most notably States et al., (1972), O'Neill et al., (1972) and Larder et al., (1985) having demonstrated promising results but the reduction in whiplash was disappointingly low, 5-24\%. O'Neill had a large database,

Correspondence: $\operatorname{Dr}$ F. Morris, Senior Registrar in Accident and Emergency Medicine, University College Hospital, Gower Street, London WC1A 6AU, England. 
but the study had the inherent flaw that all information came from insurance claims, potentialy a very unreliable source (Gotlen, 1956; Miller, 1961).

This study was designed to investigate the protective nature, if any, of the headrestraint with regard to whiplash sustained in rear bumper impacts.

\section{DEFINITION}

Whiplash is an imprecise term, often used by the lay person to denote any injury to the neck sustained in a road-traffic accident. It implies that the neck behaves as a whip, that is, a low-velocity, high-energy imput at the base producing a high-velocity excursion at the tip. An alternative phrase, used in 1965 by $\mathrm{McNab}$, is 'acceleration extension injury'. However, 'acceleration hyperextension injury' would be a more precise term and this is the definition implied when whiplash is used in the text.

\section{METHODS}

During an 11-month-period, a study was made of all patients who presented of their own volition to the Accident \& Emergency Department at Oldchurch Hospital Romford, complaining of neck symptoms after rear-bumper impact. Patients who haf sustained their injury in any other type of impact, or who did not have neck symptomswere not included. The accident \& emergency senior house officers then filled in a pra forma, stating both personal details: age, address, A \& E number, and so forth, and accident details: car type, seat-belt usage, position in car, estimated speed of impact, and finally whether a head-restraint was fitted. Once completed, the pro forma was filed separately from the patients' notes. The patients were examined, X-rays taken of the cervical spine only if it was deemed necessary, and the patients were treated symptomatically with cervical collars, analgesia, reassurance and asked to return within a week for review.

The review was undertaken by the author, when neck movements, neurology of the upper limbs and X-ray findings were noted. Only the patients' notes were available and therefore the patients' head-restraint status was unknown. Treatment then consisted of an explanation of the nature of the injury and the symptoms experienced, followed by encouragement of active movements, heat application, massage and swimming. All patients who stil had significant symptoms at 2 weeks were sent to physiotherapy. No attempt was made to recall patients who failed to return for review.

As there are no official figures at the Department of Transport, concerning the headrestraints status of passenger cars, on 16 October 1987 a total of 5000 passenger cars were counted in Romford, Essex and the percentage fitted with head-restraints tabulated. A total of 2500 consecutive passenger cars were counted on the A12 (the nearest ' $A$ ' road to the hospital) from $0800 \mathrm{~h}$, and a further 2500 consecutive passenger cars on Waterloo Road, Romford (the ' $B$ ' road on which the hospital stands), directly afterwards. 
Table 1

\begin{tabular}{lll}
\hline & Whiplash injury & Cars moving on 'A' roads \\
\hline Cars not fitted with head-restraint & $68(64 \%)$ & $1552(31 \%)$ \\
Cars fitted with head-restraint & $38(36 \%)$ & $3448(69 \%)$ \\
\hline
\end{tabular}

$\chi^{2}=52 \cdot 7$ with a significant $P<0.0001$.

\section{RESULTS}

A total of 106 consecutive patients who had sustained whiplash injury due to rear bumper collision were studied. Twenty-eight patients $(24 \%)$ did not return for review. Only six $(5.6 \%)$ patients were seated in the rear seats at the time of the impact; these, together with five $(4 \cdot 7 \%)$ front-seat passengers, were not restrained by seat-belts. Sixty-eight (64\%) patients did not have a head-restraint fitted. The number of cars not fitted with a head-restraint was $1522(31 \%)$.

The results were analysed statistically on an IBM personal computer with a SPSSPC programme using the $\chi^{2}$ test.

This illustrates that there was a highly significant difference between the expected number of people ( $31 \%$ ) who would not have a head-restraint fitted when they sustained whiplash, and the actual number of people who did not have a head-restraint when they sustained whiplash $(64 \%)$.

None of the patients studied clinically or radiologically were suspected of having sustained bony injury to the cervical spine and in the group of patients in whom they were prolonged symptoms, there was no clinical evidence that any other new pathology, for example disc protrusion, had been provoked. However, a number of patients had symptoms compatible with cervical spondylosis.

\section{DISCUSSION}

The majority of new cars sold in this country are fitted with head-restraints, but as approximately $30 \%$ of all passenger cars on the road in this country do not have them fitted as standard, it is of importance to know whether they convey any protection against whiplash, particularly as there is some evidence to suggest that seat-belt restraint may increase the severity of whiplash (Hobbs, 1981; Rutherford et al., 1985).

The significant difference in incidence of whiplash demonstrated in this study might be partially explained by the fact that some people complaining of neck symptoms after a rear-bumper injury went elsewhere for their primary care. It might be postulated that a disproportionate number of these people not only could afford new cars (with headrestraints) but also alternative private medical care. Of the $28 \%$ of patients who failed to return for review, it is possible that their symptoms had resolved, or that they made alternative arrangements for follow-up and it is interesting to note that of these 28 
patients, $15(54 \%)$ were without head-restraint at the time of impact, and $13(45 \%)$ did have head-restraints.

Rear-bumper impacts account for $20-30 \%$ of all types of car accidents (Langwieder $e t$ al., 1982; McNab, 1977; States, 1979) and it has been stated (Deans, 1987) that these give rise to a disproportionately high incidence of neck injury compared with other mechanisms of impact. The reported percentage of rear-bumper injury in this country is in fact lower, but an analysis of car-accident reporting in this country shows how this discrepency can be accounted for. The Transport and Road Research Laboratory, Crowthorne, collects data on road-traffic accidents reported to them by the police, who only routinely attend accidents where there has been obvious injury, their presence at other accidents depending upon manpower availability. Given that whiplash symptoms may not be present initially, and that rear-end impacts of as little as $5 \mathrm{mph}$ can give rise to significant symptoms, the true figure is probably higher. For practical reasons, no attempt was made to ensure that head-restraints fitted to the cars in the study were:

(1) at an optimal height for the vehicle occupants (in one study, $75 \%$ of all adjustable head-restraints were found to be in the down position at the time of the impact) (Garrett \& Morris, 1972);

(2) fitted so that there was less than $25 \mathrm{~mm}$ between the occupants' occiput and the head-restraint;

(3) were not faulty in design, or fitting, all points which have shown to be of some importance (O'Neill et al., 1972; Fox et al., 1976).

The demonstrated marked difference of incidence of whiplash between the two groups may be even more significant if the above considerations were taken inte account.

\section{CONCLUSIONS}

This study has shown a marked increase in the incidence of whiplash in the unrestrained neck compared with the restrained neck. the symptoms can persist for long periods, especially in the ageing cervical spine, and it constitutes an easily preventable health problem. Legislation requiring all passenger cars in this country to have headrestraints fitted as standards would be a major factor in reducing whiplash injuries from rear bumper injury.

\section{ACKNOWLEDGEMENTS}

My thanks to Dr V. E. Holkar, Consultant in Charge, A \& E department to Dr A. Maddox and Dr Ellie Carr for constructive criticism and Mrs Sue Harding for typing the manuscript. 


\section{REFERENCES}

Deans G. T., Magalliard N., Malcolm K. \& Rutherford W. H. (1987) Neck sprain-a major cause of disability following car accidents. Injury 18, 10-12.

Fox et al., (1976) Mathematical model for investigating combined seat back-head-restraint performance during rear end impact. Medical and biological engineering 14, 263-73.

Garrett J. W. \& Morris D. F. (1972) 'Performance Evaluation of Automobile Headrestraints', paper 720034. Automotive Engineering Congress, Detroit, Mi., 10-14 Jan 1972.

Gotten N. (1956) Survey of one hundred cases of whiplash injury after settlement of litigation. fournal of the American Medical Association 162, 865-7.

Hobbs C. A. (1981) Car occupant injury patients and mechanisms. Transport and road research laboratory supplementary report 648.

Hohl M. (1974) Soft tissue injuries of the neck in automobile accidents. Fournal of Bone and foint Surgery 56A, 1675-82.

K. Langwieder et al., (1982). Characteristics of Neck Injuries of Car Occupants. Munchen, HUK-Verband.

Larder D. R., Twiss M. K. \& MacKay G. M. (1985) 'Injury to car occupants using seat-belts.' 29th Anniversary proceedings. American Association for Automative Medicine.

Mersky H. (1984) Psychiatry and the cervical pain syndrome. Canadian Medical Association fournal 130, 1119-21.

Miller H. (1961) Accident neurosis. British Medical fournal i, 919-25, 992-8.

Whiplash injuries of the neck. American Association for Automative Medicine,

McNab 1. (1977) The whiplash syndrome, Orthopaedic Clinic (Northampton), 2, 389-403.

National Safety Council (1971) Accident Fact, 47. Chicago, Illinois.

O'Neill et al (1972) Automobile head-restraints - frequency of neck injury claims in relation to the presence of head-restraints. American fournal of Public Health 62, 399-406.

Rutherford W. H., Greenfield T., Hayes H. R. M. et al. (1985) The Medical Effects of Seat-belt Legislation in the United Kingdom. Department of Health and Social Security research report No. 13. London, HMSO.

States J. D. (1979) The human neck-anatomy, injury mechanism and biomechanic. Society of Automotive Engineers Inc. Monograph.

States J. D. et al., (1970) The enigma of whiplash injury New York State fournal of Medicine 15, 2671-79.

States J. D. et al., (1972) 'Injury frequency and head-restraint effectiveness in rear end impact accidents.' 16th Stapp Car Crash Conference, p. 228-257. New York, Society of Automotive Engineers. 